SOUZA JUNIOR, Jarbas Paula de. Responsabilidade civil do Estado em tempos de COVID-19: breves considerações a luz das recomendações da Organização Mundial da Saúde e sob a ótica constitucional moderna dos Direitos e Garantias Fundamentais. Revista Eletrônica Direito e Política, Programa de Pós-Graduação Stricto Sensu em Ciência Jurídica da UNIVALI, Itajaí, v.15, n.3, $3^{\circ}$ quadrimestre de 2020. Disponível em: www.univali.br/direitoepolitica - ISSN 1980-7791

\title{
RESPONSABILIDADE CIVIL DO ESTADO EM TEMPOS DE COVID-19: BREVES CONSIDERAÇÕES A LUZ DAS RECOMENDAÇÕES DA ORGANIZAÇÃO MUNDIAL DA SAÚDE E SOB A ÓTICA CONSTITUCIONAL MODERNA DOS DIREITOS E GARANTIAS FUNDAMENTAIS
}

\author{
STATE CIVIL RESPONSIBILITY IN COVID-19 TIMES: BRIEF \\ CONSIDERATIONS IN THE LIGHT OF THE RECOMMENDATIONS OF THE \\ WORLD HEALTH ORGANIZATION AND FROM THE MODERN \\ CONSTITUTIONAL PERSPECTIVE OF FUNDAMETAL RIGHTS AND \\ GUARANTEES
}

Jarbas Paula de Souza Junior ${ }^{1}$

\begin{abstract}
RESUMO
A presente pesquisa tem como objeto de estudo o atual cenário de calamidade global instaurado pela Pandemia Covid-19, especialmente no que condiz a possibilidade de responsabilização civil do Estado brasileiro por omissão, em decorrência da relativização das recomendações da Organização Mundial da Saúde (OMS). Partindo-se de premissas gerais, sem a intenção de exaurir-se o assunto, serão analisadas e identificadas as características constitutivas básicas da Organização Mundial da Saúde, suas atribuições, bem como a força vinculante de subordinação às suas orientações. Além do mais, examinar-se-á a responsabilidade civil do Estado sob a ótica constitucional da eficácia direta e imediata dos direitos fundamentais, em suas obrigações negativas e em suas dimensões prestacionais, vez tratar-se à saúde de uma prestação constitucionalmente indispensável à proteção do ser humano, restando desautorizados excessos e omissões.
\end{abstract}

PALAVRAS-CHAVE: Covid-19; OMS; Dever de proteção; Responsabilidade civil estatal.

\section{ABSTRACT}

The present research has as object of study the current scenario of global calamity established by Pandemic Covid-19, especially regarding the possibility of civil liability of the Brazilian State for omission, due to the relativization of the recommendations of the World Health Organization (WHO) . Starting from general premises, without the intention of exhausting the subject, the basic constitutive characteristics of the World Health Organization, its attributions, as

\footnotetext{
1 Mestrando em Direito pela Faculdade Meridional - IMED, Pós Graduado em Direito Processual Civil (URI-FW), Direito Tributário (Unoesc), Direito Médico e Hospitalar (EPD-SP) e Direito da Medicina (Coimbra-PT)
} 
SOUZA JUNIOR, Jarbas Paula de. Responsabilidade civil do Estado em tempos de COVID-19: breves considerações a luz das recomendações da Organização Mundial da Saúde e sob a ótica constitucional moderna dos Direitos e Garantias Fundamentais. Revista Eletrônica Direito e Política, Programa de Pós-Graduação Stricto Sensu em Ciência Jurídica da UNIVALI, Itajaí, v.15, n.3, 30 quadrimestre de 2020. Disponível em: www.univali.br/direitoepolitica - ISSN 1980-7791

well as the binding force of subordination to its guidelines will be analyzed and identified. In addition, the State's civil liability will be examined from the constitutional point of view of the direct and immediate effectiveness of fundamental rights, in their negative obligations and in their service dimensions, since health is a constitutionally essential provision for protection of the human being, leaving excesses and omissions unauthorized.

KEYWORDS: Covid-19; WHO; Duty of protection; State civil liability.

\section{INTRODUÇÃO}

O presente trabalho científico tem como propósito o estudo do atual cenário de calamidade global instaurado pela Pandemia Covid-19, especificamente no que condiz a possibilidade de responsabilização civil do Estado em decorrência da relativização das recomendações de Organismos Internacionais, particularmente, as oriundas da Organização Mundial da Saúde (OMS).

Partindo-se de premissas gerais, sem a intenção de exaurir-se o assunto, serão analisadas e identificadas as características constitutivas básicas da Organização Mundial da Saúde, suas atribuições diante da atual conjuntura, bem como a força vinculante de subordinação às suas decisões.

De igual forma, examinar-se-á a responsabilidade civil do Estado sob a ótica constitucional da eficácia direta e imediata dos direitos fundamentais, tanto em suas obrigações negativas quanto em suas dimensões prestacionais, em que pese tratar-se à saúde de uma prestação constitucionalmente indispensável à proteção do ser humano, restando desautorizados excessos e omissões.

De toda sorte, levando-se em conta à linha de pesquisa "Efetividade do Direito, da Democracia e da Sustentabilidade", dividiu-se a pesquisa em objetivos geral e específicos, conforme delineia-se abaixo.

O objetivo geral da pesquisa foi analisar a possibilidade, considerando o desrespeito às recomendações oriundas de Organismos Internacionais, particularmente, a Organização Mundial da Saúde, de responsabilização civil do Estado brasileiro por omissão no combate da Pandemia Covid-19. 
SOUZA JUNIOR, Jarbas Paula de. Responsabilidade civil do Estado em tempos de COVID-19: breves considerações a luz das recomendações da Organização Mundial da Saúde e sob a ótica constitucional moderna dos Direitos e Garantias Fundamentais. Revista Eletrônica Direito e Política, Programa de Pós-Graduação Stricto Sensu em Ciência Jurídica da UNIVALI, Itajaí, v.15, n.3, 30 quadrimestre de 2020. Disponível em: www.univali.br/direitoepolitica - ISSN 1980-7791

Por sua vez os objetivos específicos da pesquisa relacionaram-se a analisar os aspectos gerais da Organização Mundial da Saúde e a força vinculante dos seus atos e a explorar os fundamentos e requisitos da responsabilização civil do Estado, particularmente, perante o enfoque constitucional dos direitos e garantias fundamentais.

Adotou-se na pesquisa, como método de abordagem, o método dedutivo, tendo como finalidade abordar o conteúdo a partir de "argumentos gerais para argumentos particulares ${ }^{2 \prime \prime}$.

Já como método de procedimento instrumental utilizou-se predominantemente a pesquisa bibliográfica na qual foram utilizados livros, periódicos nacionais e internacionais, páginas da internet que exploram a temática alvo.

\section{ASPECTOS GERAIS DA ORGANIZAÇÃo MUNDIAL DA SAÚdE E A COERCITIVIDADE DE SEUS ATOS NORMATIVOS AOS ESTADOS MEMBROS}

Com o surgimento da Pandemia Covid-19 ganhou voga, no cenário internacional, a atuação de uma organização vinculada a Organização das Nações Unidas, criada logo após a Segunda Guerra Mundial com o objetivo de regular o padrão da saúde internacionalmente, estamos falando da Organização Mundial da Saúde.

A Organização Mundial da Saúde foi fundada em 07 de abril de 1948, a partir de uma proposta apresentada por Brasil e China, no ano de 1945, respaldando sua instituição na concepção de que todos os seres humanos têm direito a um padrão elevado de saúde ${ }^{3}$.

Atualmente a Organização Mundial da Saúde, além de integrar a agência da Organização das Nações Unidas (ONU), é o órgão responsável pela construção de estudos, relatórios e estatísticas que se preocupam com os níveis de saúde internacionais.

\footnotetext{
2 MEZZAROBA, Orides; MONTEIRO, Cláudia Servilha. Manual de metodologia da pesquisa no direito. 5 ed. São Paulo: Saraiva, 2009, p. 65.

${ }^{3}$ BERNARDO, Paulo. Brasil teve papel direto na fundação da OMS: entenda o que é a função da organização. Disponível em: <https://saude.estadao.com.br/noticias/geral,brasil-teve-papeldireto-na-fundacao-da-oms-entenda-o-que-e-e-a-funcao-da-organizacao,70003256316>. Acesso em: 06 ago. 2020.
} 
SOUZA JUNIOR, Jarbas Paula de. Responsabilidade civil do Estado em tempos de COVID-19: breves considerações a luz das recomendações da Organização Mundial da Saúde e sob a ótica constitucional moderna dos Direitos e Garantias Fundamentais. Revista Eletrônica Direito e Política, Programa de Pós-Graduação Stricto Sensu em Ciência Jurídica da UNIVALI, Itajaí, v.15, n.3, 30 quadrimestre de 2020. Disponível em: www.univali.br/direitoepolitica - ISSN 1980-7791

Consoante aduz Cabral ${ }^{4}$, a Organização Mundial da Saúde se estrutura como um organismo internacional, de forma paralela aos Estados, manifestando suas decisões por meio de atos que "possuem força normativa, tornando-se obrigatória para os Estados, sejam aquelas provenientes da hard Law ou às soft laws".

Segundo a Organização Pan-Americana da Saúde o objetivo da OMS "é ajudar a comunidade internacional a prevenir e responder a graves riscos de saúde pública que têm o potencial de atravessar fronteiras e ameaçar pessoas em todo o mundo ${ }^{5 \prime \prime}$.

Para Cabral $^{6}$ uma das principais motivações para a criação da Organização Mundial da Saúde "foi justamente a possibilidade de cooperação técnica e científica a partir do monitoramento das políticas de saúde em todo o mundo".

Podem-se citar, como exemplos, de atuação da Organização Mundial de Saúde, as campanhas de vacinação da pólio (1952-1957), a vacinação contra sarampo e rubéola (1963), o programa de imunização de vacinas para o mundo todo (1974), a eliminação da varíola (1979), a atuação no controle da AIDS, dentre outras diversas atuações no combate a moléstias que vitimaram e ainda vitimam a humanidade?

A Constituição da Organização Mundial da Saúde ${ }^{8}$, firmada em Nova York, em 22 de julho de 1946, definiu o termo saúde em seu preâmbulo como "um estado de completo bem-estar físico, mental e social e não apenas a ausência de doença ou enfermidade" e complementou que "a saúde de todos os povos é condição

\footnotetext{
${ }^{4}$ CABRAL, Cristiane Helena de Paula Lima. Organização mundial da saúde e sua atuação no âmbito da saúde pública internacional. In: BAHIA, Saulo José Casali Bahia; MARTINS, Carlos Eduardo Behrmann Rátis (Coord.). Direitos e deveres fundamentais em tempos de coronavírus. v. 2. São Paulo: Editora Iasp, 2020, p. 185.

5 OPAS. Organização pan-americana da saúde. Disponível em: <https://www.paho.org/bra/index.php?option=com_content\&view=article\&id=885:opas-omsnobrasil\&Itemid=672>. Acesso em: 06 ago. 2020.

${ }^{6}$ CABRAL, Cristiane Helena de Paula Lima. p. 189.

7 OMS. Organização Mundial da Saúde. Disponível em: <https://www.who.int/es>. Acesso em: 06 ago. 2020.

${ }^{8}$ O Brasil ratificou a Constituição da Organização Mundial da Saúde pelo Decreto n 26.042, de 17 de dezembro de 1948.
} 
SOUZA JUNIOR, Jarbas Paula de. Responsabilidade civil do Estado em tempos de COVID-19: breves considerações a luz das recomendações da Organização Mundial da Saúde e sob a ótica constitucional moderna dos Direitos e Garantias Fundamentais. Revista Eletrônica Direito e Política, Programa de Pós-Graduação Stricto Sensu em Ciência Jurídica da UNIVALI, Itajaí, v.15, n.3, 30 quadrimestre de 2020. Disponível em: www.univali.br/direitoepolitica - ISSN 1980-7791

fundamental para se chegar à paz, a segurança e depende da mais ampla cooperação das pessoas e dos Estados ${ }^{9 \prime \prime}$.

Desta forma, constata-se ter a Organização Mundial da Saúde a responsabilidade, juntamente com os Estados e demais atores internacionais, de consolidar, de forma irrestrita e universal, os instrumentos para manutenção da saúde. Passa, assim, a saúde a ser entendida como um direito "direito global", uma "saúde global ${ }^{10 "}$.

Ao abordar o assunto ponderam Brown, Cueto e Fee ${ }^{11}$ que:

A expressão 'saúde global' é, por vezes, apresentada como uma resposta puramente racional a eventos novos e ameaçadores na saúde pública, tais como epidemias internacionais atingindo tanto países ricos como países pobres, e a migração ilegal de populações. Como mostramos neste artigo, essa expressão emergiu como parte de um processo histórico e político mais amplo, em meio a um debate ainda não resolvido sobre a direção que deve tomar a saúde pública, no contexto de uma ordem mundial neoliberal, no qual a OMS viu seu papel, antes dominante, ser desafiado, e começou a reposicionar-se no âmbito de um conjunto de alianças de poder em transformação.

A Organização Mundial da Saúde possui, entre outras funções, consoante o artigo $2^{\circ}$, da sua Constituição ${ }^{12}$, a de "atuar como autoridade diretora e coordenadora dos trabalhos internacionais em assuntos relativos à saúde", bem como "estabelecer e manter colaboração efetiva com as Nações Unidas, as agências especializadas, as repartições governamentais de saúde, os grupos profissionais e quaisquer outras organizações que pareçam indicadas ${ }^{13 \prime}$.

\footnotetext{
${ }^{9}$ BRASIL, Decreto no 26.042 (Constituição da Organização Mundial da Saúde). 1948. Disponível em: <https://www2.camara.leg.br/legin/fed/decret/1940-1949/decreto-26042-17-dezembro1948-455751-publicacaooriginal-1-pe.html>. Acesso em: 7 ago. 2020.

${ }^{10}$ CABRAL, Cristiane Helena de Paula Lima. p. 193.

11 BROWN, Theodore M.; CUETO, Marcos; FEE, Elizabeth. A transição de saúde pública 'internacional' para 'global' e a Organização Mundial da Saúde. Disponível em: $<$ https://www.scielo.br/scielo.php?script=sci_arttext\&pid=S0104$59702006000300005 \&$ Ing=pt\&tlng=pt>. 2006. Acesso em 07 de ago. de 2020, p. 641.

12 O Brasil ratificou e aprovou a referida Constituição da Organização Mundial da Saúde pelo Decreto n० 26.042, de 17 de dezembro de 1948.

${ }^{13}$ BRASIL, Decreto no 26.042 (Constituição da Organização Mundial da Saúde).
} 
SOUZA JUNIOR, Jarbas Paula de. Responsabilidade civil do Estado em tempos de COVID-19: breves considerações a luz das recomendações da Organização Mundial da Saúde e sob a ótica constitucional moderna dos Direitos e Garantias Fundamentais. Revista Eletrônica Direito e Política, Programa de Pós-Graduação Stricto Sensu em Ciência Jurídica da UNIVALI, Itajaí, v.15, n.3, 30 quadrimestre de 2020. Disponível em: www.univali.br/direitoepolitica - ISSN 1980-7791

Reza o artigo 21 a Constituição da Organização Mundial da Saúde que a Assembleia da Saúde poderá adotar regulamentos concernentes, "às medidas sanitárias e de quarentena ou outro qualquer processo com o fim de impedir a propagação de doenças de um país a outro ${ }^{14 \prime \prime}$.

Em 2007, com o propósito de auxiliar no combate de emergência em saúde pública, utilizando-se das experiências acumuladas com os tratamentos da Pandemia do vírus influenza $A(H 1 N 1)$ foi elaborado o Regulamento Sanitário Internacional $(\mathrm{RSI})^{15}$. Dispõe o artigo $1^{\circ}$, que emergência de saúde pública de importância internacional significa:

[...] um evento extraordinário que, nos termos do presente Regulamento, é determinado como: (i) constituindo um risco para a saúde pública para outros Estados, devido à propagação internacional de doença e; (ii) potencialmente exigindo uma resposta internacional coordenada;".

Ultrapassada a introdutória análise e identificação das características constitutivas básicas da Organização Mundial da Saúde, bem como de suas atribuições, verifica-se, diante da atual crise sanitária internacional - instaurada pela Pandemia Covid-19 e da celeuma instaurada sobre a obrigatoriedade de observância das suas recomendações -, a necessidade de se identificar a natureza dos atos exarados pela Organização Mundial da Saúde.

Assevera o artigo 19 da Constituição da Organização Mundial da Saúde ${ }^{16}$ :

A Assembleia de Saúde tem autoridade para efetuar convenções e acordos a respeito de qualquer assunto que seja de alçada da Organização. A maioria de dois terços dos votos é necessária para a adoção de tais convenções ou acordos, os quais entrarão em vigor para cada Estado Membro quando aceitos por este de acordo com os dispositivos de suas respectivas constituições.

Nessa perspectiva o artigo 21 , do citado diploma de saúde ${ }^{17}$, dispõe que a Assembleia poderá adotar regulamentos concernentes "às medidas sanitárias e

\footnotetext{
${ }^{14}$ BRASIL, Decreto no 26.042 (Constituição da Organização Mundial da Saúde).

${ }^{15}$ O Brasil ratificou e aprovou o referido Regulamento pelo Decreto Legislativo no 395, de 13 de março de 2009.

${ }^{16}$ BRASIL, Decreto no 26.042 (Constituição da Organização Mundial da Saúde).
} 
SOUZA JUNIOR, Jarbas Paula de. Responsabilidade civil do Estado em tempos de COVID-19: breves considerações a luz das recomendações da Organização Mundial da Saúde e sob a ótica constitucional moderna dos Direitos e Garantias Fundamentais. Revista Eletrônica Direito e Política, Programa de Pós-Graduação Stricto Sensu em Ciência Jurídica da UNIVALI, Itajaí, v.15, n.3, 30 quadrimestre de 2020. Disponível em: www.univali.br/direitoepolitica - ISSN 1980-7791

de quarentena ou qualquer outro processo com o fim de impedir a propagação de doenças de um país a outro", da mesma maneira que poderá regulamentar "padrões com respeito a processos de diagnósticos para uso internacional" e "padrões relativos à garantia, pureza e atividade dos produtos biológicos, farmacêuticos e similares que se encontram no comércio internacional.".

Além de tudo, o artigo 62 da Constituição da Organização Mundial da Saúde ${ }^{18}$ assenta que cada Estado Membro apresentará anualmente um relatório sobre as medidas tomadas em relação às recomendações que the forem feitas pela Organização e em relação às convenções, acordos e regulamentos.

Ao tratar da submissão dos Estados Membros às recomendações expedidas pela Organização Mundial da Saúde destaca Cabral ${ }^{19}$ que:

[...] considerando às medidas propostas pela OMS para a contenção e prevenção da COVID-19, os Estados devem tomar medidas para adotá-las, uma vez que elas possuem força obrigatória, independentemente da sua natureza, seja hard Law (Constituição da OMS e o Regulamento) ou soft Law (os inúmeros protocolos), não havendo no que se falar em ausência de cumprimento.

Todavia, as deliberações da Organização Mundial da Saúde por se tratarem de medidas de caráter supranacional, meramente simbólicas, ressentem-se, assim como ocorre com o direito internacional, de instrumentos voltados para a eficácia da efetividade das suas decisões - suas decisões não possuem força vinculante e de subordinação.

Ocorre que, Inexiste, no ambiente do direito internacional e, consequentemente, da Organização Mundial da Saúde, meios coercitivos para se fazer cumprir as suas diretrizes, salvo, eventual, medida de exposição dos Estados Membros "infratores" no cenário internacional.

Infelizmente, fica a cargo de cada Estado Membro a adoção das recomendações da OMS, seja para a contenção de doenças ou para outra medida qualquer. A

\footnotetext{
17 BRASIL, Decreto no 26.042.

${ }^{18}$ BRASIL, Decreto no 26.042 (Constituição da Organização Mundial da Saúde).

${ }^{19}$ CABRAL, Cristiane Helena de Paula Lima. p. 195.
} 
SOUZA JUNIOR, Jarbas Paula de. Responsabilidade civil do Estado em tempos de COVID-19: breves considerações a luz das recomendações da Organização Mundial da Saúde e sob a ótica constitucional moderna dos Direitos e Garantias Fundamentais. Revista Eletrônica Direito e Política, Programa de Pós-Graduação Stricto Sensu em Ciência Jurídica da UNIVALI, Itajaí, v.15, n.3, 30 quadrimestre de 2020. Disponível em: www.univali.br/direitoepolitica - ISSN 1980-7791

ausência de um órgão com poderes jurisdicional de polícia e sancionatórios, com atribuição e competência para julgar os Estados Membros, diante de circunstancial violação das suas deliberações, coloca em xeque a própria existência da OMS.

Apesar disso, como pondera Cabral ${ }^{20}$ :

[...] esse cenário de Pandemia da COVID-19 serviu para mostrar a importância de se redescobrir o Direito Internacional e o papel das Organizações Internacionais, conforme os dizeres de Wagner Menezes, Valério de Oliveira Mazzuoli e Luigi Ferrajoli, uma vez que a atuação desses organismos não estão sendo capazes de enfrentar as questões que a COVID-19 colocou à prova.

Torna-se imperioso, dessa forma, que se busque inovar, no âmbito do direito internacional e da própria Organização Mundial da Saúde, com a concepção de novos instrumentos normativos, singularmente de cunho sancionatório, sujeitando e subordinando os Estados Membros as suas deliberações. Somente, desse modo, poderão ser evitados danos irreparáveis a saúde da humanidade.

\section{DO DEVER DE PROTEÇÃo do ESTADO EM RELAÇÃo À SAÚde No COMBATE A PANDEMIA COVID-19}

A problemática atual, atinente a responsabilidade civil do Estado, em muito se distingue daquela decorrente da sociedade pós-industrial. A evolução social nos conduziu a um novo modelo de desenvolvimento, passamos de uma sociedade agrícola e industrial, para uma sociedade da informação, extremamente interligada e globalizada, lastreada em novos desafios e, como conseguinte, instrumentalizada por novos direitos dos cidadãos e deveres do Estado.

Ferrajoli" ${ }^{21}$ expõe, em uma breve resenha, sob título "O vírus põe a globalização de joelhos", o caráter universal da contaminação:

${ }^{20}$ CABRAL, Cristiane Helena de Paula Lima. p.196.

21 FERRAJOLI, Luigi. O vírus põe a globalização de joelhos. Revista do Instituto Humanitas UNISINOS. 2020. Disponível em: <http://www.ihu.unisinos.br/78-noticias/597204-o-virus-poe-aglobalizacao-de-joelhos-artigo-de-luigi-ferrajoli>. Acesso em: 7 ago. 2020. 
SOUZA JUNIOR, Jarbas Paula de. Responsabilidade civil do Estado em tempos de COVID-19: breves considerações a luz das recomendações da Organização Mundial da Saúde e sob a ótica constitucional moderna dos Direitos e Garantias Fundamentais. Revista Eletrônica Direito e Política, Programa de Pós-Graduação Stricto Sensu em Ciência Jurídica da UNIVALI, Itajaí, v.15, n.3, 30 quadrimestre de 2020. Disponível em: www.univali.br/direitoepolitica - ISSN 1980-7791

Apesar das conquistas tecnológicas, do crescimento das riquezas e da invenção de armas cada vez mais letais, continuamos - todos, simplesmente como seres humanos a estar expostos às catástrofes. Com uma diferença em comparação com todas as tragédias do passado: o caráter global das catástrofes atuais, que afetam todo o mundo, a humanidade inteira, sem diferença de nacionalidade, de cultura, de língua, de religião e até de condições econômicas e políticas.

A catastrófica situação de emergência sanitária internacional, vivenciada após o surgimento do vírus Covid-19 enseja, por parte do Estado, uma maior atenção na adoção de providencias eficientes para o enfrentamento da crise global de saúde. Compete ao Estado garantir a preservação dos direitos fundamentais, máxime o direito à saúde, em face dessa inevitável agressão instaurada pela Pandemia Covid-19, ainda, que não seja, vale ressaltar, um "segurador, garantidor universal".

Esclarecem Dimoulis e Martins ${ }^{22}$ que:

O Estado deve fundamentar suas ações e omissões, e deve, conforme dissemos, não só se abster de agredir direitos fundamentais (dever de abstenção), mas também evitar agressões provindas de outros atores sociais. Nesse sentido, "parte da doutrina e jurisprudência identifica os denominados deveres estatais de tutela (staatliche Shutzplichten). O termo indica o dever do Estado de proteger ativa e preventivamente o direito fundamental contra ameaças de agressões provenientes, principalmente, de particulares. Em outras palavras, considera-se que o particular também possa de fato e, em regra, mediante o exercício de outro direito fundamental seu, agredir o direito fundamental objeto do dever estatal de tutela em uma situação que envolva irreparabilidade da possível lesão, incontrolabilidade de processos ameaçadores de direitos fundamentais sensíveis ou conflito caracterizados por clara e acentuada assimetria de forças, chances e condições entre agentes particulares envolvidos em conflito. Por isso, encontram-se, sob o gênero dos deveres estatais de tutela, as categorias de dever de mera prevenção de riscos, do dever de fomentar a segurança e, até mesmo, do dever de proibição de condutas a ser imposto pelo Estado".

22 DIMOULIS, Dimitri; MARTINS, Leonardo. Teoria geral dos direitos fundamentais. São Paulo: atlas, 2012, p. 60. 
SOUZA JUNIOR, Jarbas Paula de. Responsabilidade civil do Estado em tempos de COVID-19: breves considerações a luz das recomendações da Organização Mundial da Saúde e sob a ótica constitucional moderna dos Direitos e Garantias Fundamentais. Revista Eletrônica Direito e Política, Programa de Pós-Graduação Stricto Sensu em Ciência Jurídica da UNIVALI, Itajaí, v.15, n.3, 30 quadrimestre de 2020. Disponível em: www.univali.br/direitoepolitica - ISSN 1980-7791

É nesta conjuntura "de tutela estatal de direitos fundamentais" que se discorrerá acerca da responsabilidade civil do Estado, tanto por ação como por omissão, no contexto da Pandemia Covid-19.

De atentar, prefacialmente, que o ordenamento jurídico brasileiro proclamou que a responsabilidade civil do Estado, em regra, é objetiva, a teor do que reza o artigo. 37, § 60, da Constituição Federal ${ }^{23}$.

De destacar que referida responsabilidade civil do Estado, sem culpa, não é uma novidade introduzida com a Constituição Federal de 1988, esse dever de indenizar já encontrava previsão legal no ordenamento jurídico brasileiro desde a Constituição de 1946.

A responsabilidade objetiva do Estado está alicerçada na teoria do risco administrativo, sendo que aludida teoria, nas palavras de Cavalieri Filho ${ }^{24}$ pode ser assim formulada:

[...] a Administração Pública gera riscos para os administrados, entendendo-se como tal a possibilidade de dano que os membros da comunidade podem sofrer em decorrência da normal ou anormal atividade do Estado. Tendo em vista que essa atividade é exercida em favor de todos, seus ônus devem ser também suportados por todos, e não apenas por alguns. Consequentemente, deve o Estado, que a todos representa, suportar os ônus da sua atividade, independentemente de culpa dos seus agentes.

Impende atentar que não há que se confundir a teoria do risco administrativo com a teoria do risco integral ${ }^{25}$. Seguindo a linha doutrinária de Cavalieri Filho ${ }^{26}$,

\footnotetext{
${ }^{23}$ Art. 37. A administração pública direta e indireta de qualquer dos Poderes da União, dos Estados, do Distrito Federal e dos Municípios obedecerá aos princípios de legalidade, impessoalidade, moralidade, publicidade e eficiência e, também, ao seguinte:

$[\ldots]$

$\S 6^{\circ}$ As pessoas jurídicas de direito público e as de direito privado prestadoras de serviços públicos responderão pelos danos que seus agentes, nessa qualidade, causarem a terceiros, assegurado o direito de regresso contra o responsável nos casos de dolo ou culpa.
}

${ }^{24}$ CAVALIERI FILHO, Sergio. Programa de responsabilidade civil. 14. ed. São Paulo: Atlas. 2020, p. 286.

25 De acordo com Cavalieri Filho (2020, p. 196) "A teoria do risco integral é uma modalidade extremada da doutrina do risco destinada a justificar o dever de indenizar até nos casos de inexistência de nexo causal [...]. Na responsabilidade fundada no risco integral, todavia, o dever de indenizar é imputado àquele que cria o risco, ainda que a atividade por ele exercida não tenha sido a causa direta e imediata do evento. Bastará que a atividade de risco tenha sido a ocasião, mera 
SOUZA JUNIOR, Jarbas Paula de. Responsabilidade civil do Estado em tempos de COVID-19: breves considerações a luz das recomendações da Organização Mundial da Saúde e sob a ótica constitucional moderna dos Direitos e Garantias Fundamentais. Revista Eletrônica Direito e Política, Programa de Pós-Graduação Stricto Sensu em Ciência Jurídica da UNIVALI, Itajaí, v.15, n.3, 30 quadrimestre de 2020. Disponível em: www.univali.br/direitoepolitica - ISSN 1980-7791

tal distinção se faz necessária "para que o Estado não venha a ser responsabilizado naqueles casos em que o dano não decorra direta ou indiretamente da atividade administrativa.".

Oportunamente agrega Cavalieri Filho ${ }^{27}$ que, acaso se admitisse a teoria do risco integral na avaliação da responsabilidade da Administração Pública, "ficaria o Estado obrigado a indenizar sempre e em qualquer caso o dano suportado pelo particular, ainda que não decorrente de sua atividade, posto que estaria impedido de invocar as causas de exclusão do nexo causal.".

Ocorre que, apesar da teoria do risco administrativo dispensar a análise da culpa, a verificação da relação de causalidade, entre o dano perpetrado e a atividade executada pelo Estado, é essencial para caracterização do dever de indenizar, independentemente da modalidade da responsabilização - objetiva ou subjetiva.

Ao abordar a responsabilidade do Estado e o princípio da proporcionalidade, Freitas $^{28}$ afirma que:

[...] os requisitos da responsabilidade estatal objetiva compõem, em grandes traços, uma tríade: a existência de dano material ou imaterial, juridicamente injusto e desproporcional; o nexo causal direto e, finalmente, a conduta omissiva ou comissiva do agente da pessoa jurídica de direito público ou de direito privado prestadora de serviço público, nessa qualidade.

Entretanto, apesar da teoria do risco administrativo ter sido internalizada pelo ordenamento jurídico brasileiro como diretriz, impende-se observar que, a imputação de responsabilidade objetiva ao Estado, comporta algumas exceções. São causas de exclusão do dever de indenizar estatal: o fato exclusivo da vítima, o caso fortuito ou força maior e o fato exclusivo de terceiro.

causa mediata ou indireta do vento, ainda que se tenha tido por causa direta e imediata fato irresistível ou inevitável, como a força maior e o caso fortuito.".

${ }^{26}$ CAVALIERI FILHO, Sergio. p. 287.

27 CAVALIERI FILHO, Sergio. p. 287.

28 FREITAS, Juarez. A responsabilidade extracontratual do estado e o princípio da proporcionalidade: vedação de excesso e de omissão. Revista de Direito Administrativo. n. 241. Rio de Janeiro, 2005, p. 28. 
SOUZA JUNIOR, Jarbas Paula de. Responsabilidade civil do Estado em tempos de COVID-19: breves considerações a luz das recomendações da Organização Mundial da Saúde e sob a ótica constitucional moderna dos Direitos e Garantias Fundamentais. Revista Eletrônica Direito e Política, Programa de Pós-Graduação Stricto Sensu em Ciência Jurídica da UNIVALI, Itajaí, v.15, n.3, 30 quadrimestre de 2020. Disponível em: www.univali.br/direitoepolitica - ISSN 1980-7791

Nessa toada, o risco administrativo do Estado e, logicamente, sua responsabilização civil, tanto podem se originar de atos comissivos como também de atos omissivos. Como exemplos na conjuntura da Pandemia Covid19, poder-se-ia citar: o dano sofrido por cidadão que morre em decorrência da ausência de leito ou respirador em número insuficiente.

À vista disso, optou-se por adotar a corrente doutrinária de Juarez de Freitas ${ }^{29}$, dentre outros constitucionalistas modernos, que bem relaciona à responsabilidade civil do Estado a eficácia, direta e imediata, dos direitos fundamentais, vedando-se excessos e omissões.

Segundo o entendimento do citado catedrático, o dano, situa-se na esfera de risco da atividade estatal, sendo o Estado responsabilizado independentemente de culpa - tanto por condutas comissivas como por omissivas.

Isto posto, incumbe-nos ponderar que a tónica correspondente a responsabilidade civil do Estado encontra refugio na tutela dos direitos fundamentais. Nesse sentido, argumenta Freitas ${ }^{30}$ que:

[...] o Estado brasileiro precisa ser responsável pela eficácia direta e imediata dos direitos fundamentais, já em suas obrigações negativas, já em suas dimensões prestacionais. Será, nessa perspectiva, proporcionalmente responsabilizável, tanto por ações como por omissões [...].

Dessa maneira, torna-se irrelevante, para referida concepção da responsabilidade estatal, a prova da culpa. Da mesma forma, a querela sobre a previsibilidade ou não do dano, visto que, como linha de tendência, há que se sopesar meramente se houve ou não a observância das medidas preventivas de cuidado e proteção.

Acrescenta Peces-Barba ${ }^{31}$ que "os sentidos atuais relacionam-se com 0 fundamento dos direitos humanos, com o fundamento dos deveres jurídicos

${ }^{29}$ Autor das obras: 1) Responsabilidade Civil do Estado e o princípio da proporcionalidade: vedação de excesso e de inoperância. São Paulo: Malheiros, 2006; 2) A responsabilidade extracontratual do Estado e o princípio da proporcionalidade. Revista de Direito Administrativo. Rio de Janeiro, 2005; e A Constituição, a responsabilidade do Estado e a eficácia direta e imediata dos direitos fundamentais. Constituição e crise política. Belo Horizonte: Del Rey, 2006.

30 FREITAS, Juarez. A responsabilidade extracontratual do estado e o princípio da proporcionalidade. p. 381. 
SOUZA JUNIOR, Jarbas Paula de. Responsabilidade civil do Estado em tempos de COVID-19: breves considerações a luz das recomendações da Organização Mundial da Saúde e sob a ótica constitucional moderna dos Direitos e Garantias Fundamentais. Revista Eletrônica Direito e Política, Programa de Pós-Graduação Stricto Sensu em Ciência Jurídica da UNIVALI, Itajaí, v.15, n.3, 30 quadrimestre de 2020. Disponível em: www.univali.br/direitoepolitica - ISSN 1980-7791

positivados (e dos direitos difusos e coletivos) e ainda como forma de cooperação social".

Portanto, na análise da eventual responsabilidade estatal, decorrente de caso fortuito ou fenômeno da natureza - a Pandemia Covid-19 é um caso típico -, bastaria examinar-se se, o agravamento da situação de calamidade pública, deuse, única e exclusivamente, pela ausência da adoção das correlatas medidas preventivas indicadas cientificamente ao Estado.

Nesse condão, necessário reforçar que, hodiernamente, o Estado não só é obrigado a se abster de violar direitos fundamentais, como deve impreterivelmente salvaguardar os bens jurídicos fundamentais de injustas violações, como se atuasse como um "garantidor de direitos fundamentais".

Para Baptista ${ }^{32}$ :

\begin{abstract}
Está havendo, em todos os domínios jurídicos, uma releitura dos velhos conceitos à luz dos paradigmas dos princípios e direitos fundamentais. O direito administrativo começa a perceber as mudanças que isso implica em sua disciplina: "Das condições de súdito, de mero sujeito subordinado à administração, o administrado foi elevado à condição de cidadão. Essa nova posição do indivíduo, amparada no desenvolvimento do discurso dos direitos fundamentais, demandou a alteração do papel tradicional da administração pública. Direcionada para o respeito, à dignidade da pessoa humana, a administração, constitucionalizada, vê-se compelida a abandonar o modelo autoritário de gestão da coisa para se transformar em um centro de captação e ordenação dos múltiplos interesses existentes no substrato social".
\end{abstract}

A preservação das normas constitucionais fundamentais, frente às recentes formas de transgressão, é medida que se impõe obrigatoriamente. FleinerGerster $^{33}$ explicam que:

31 PECES-BARBA, Gregório. Curso de derechos fundamentales. Teoria General. Madri: Universidad Carlos III, 1995, p. 263.

32 BAPTISTA, Patrícia. Transformações do direito administrativo. Rio de Janeiro: Renovar, 2003, p. 129-130.

${ }^{33}$ FLEINER-GERSTER, Thomas. Teoria geral do estado. São Paulo: Martins Fontes, 2006, p. 160. 
SOUZA JUNIOR, Jarbas Paula de. Responsabilidade civil do Estado em tempos de COVID-19: breves considerações a luz das recomendações da Organização Mundial da Saúde e sob a ótica constitucional moderna dos Direitos e Garantias Fundamentais. Revista Eletrônica Direito e Política, Programa de Pós-Graduação Stricto Sensu em Ciência Jurídica da UNIVALI, Itajaí, v.15, n.3, 30 quadrimestre de 2020. Disponível em: www.univali.br/direitoepolitica - ISSN 1980-7791

[...] o Estado moderno não deve, como no passado, proteger o cidadão tão somente dos ladrões, assassinos e outros malfeitores, mas a sua tarefa de proteção ampliou-se consideravelmente. De fato as dependências e as interações cada vez maiores do ser humano conduziram não só à ampliação das possibilidades de comunicação mas também a uma ampliação dos perigos aos quais o homem está exposto. O Estado é então obrigado a assumir novas tarefas em matéria de proteção.

O atual momento de instabilidade mundial na área de saúde, decorrente da Pandemia Covid-19, é emblemático neste sentido. Destarte, é notório que a Covid-19 vitimaria uma extensa parcela da população brasileira, independentemente das medidas preventivas adotadas. O vírus infectou cidadãos em praticamente todo o globo terrestre, sendo ilógico imaginarmos que o território nacional seria exceção.

Nessa sentido, oportuno acentuar ser manifesto que o Estado não se trata de um "segurador, garantidor universal", como referido anteriormente, e, em vista disso, desde que implementados os correlatos programas de prevenção e combate à doença, dentro de protocolos científicos nacional e internacionalmente reconhecidos - ainda que, de forma insuficiente para eliminar por completo o contágio da enfermidade-, não há que se falar em responsabilidade civil e dever de reparar ao Estado.

Por isso, consoante Bisneto, Santos e Cavet $^{34}$ :

A ineficiência ou a ausência de adoção de medidas políticas, sociais e econômicas que visam à prevenção da disseminação da COVID-19 e seus desdobramentos, pela Administração Pública, pode gerar o dever de reparar os danos causados aos que forem lesados. Entretanto, não é qualquer omissão do Estado que ensejaria a responsabilidade civil. Seria necessária uma omissão qualificada (específica), ou seja, aquela que, além de decorrer de um dever legal particular, é causa direta e imediata do dano.

34 BISNETO, Cícero Dantas; SANTOS, Romualdo Baptista dos; CAVET, Caroline Amadori. Responsabilidade civil do estado por omissão e por incitação na pandemia da covid-19. Revista IBERC. v. 3, n. 2, maio/ago. 2020. Disponível em: <https://revistaiberc.responsabilidadecivil.org/iberc/article/view/111>. Acesso em 07 de ago. de 2020, p. 79. 
SOUZA JUNIOR, Jarbas Paula de. Responsabilidade civil do Estado em tempos de COVID-19: breves considerações a luz das recomendações da Organização Mundial da Saúde e sob a ótica constitucional moderna dos Direitos e Garantias Fundamentais. Revista Eletrônica Direito e Política, Programa de Pós-Graduação Stricto Sensu em Ciência Jurídica da UNIVALI, Itajaí, v.15, n.3, 30 quadrimestre de 2020. Disponível em: www.univali.br/direitoepolitica - ISSN 1980-7791

Lamentavelmente, nem sempre as recomendações divulgadas por entidades, como a Organização Mundial da Saúde, são eficientes para impulsionar os entes estatais na adoção de medidas de prevenção. Logo, nem todos os efeitos da Pandemia COVID-19 podem ser caracterizados como inevitáveis, hipótese em que incorrerá o ente estatal a subsunção na figura da responsabilidade civil subjetiva por omissão.

Staffen $^{35}$ é cirúrgico ao discorrer sobre a irresponsabilidade estatal no enfrentamento a Pandemia Covid-19:

Líderes de Estado e de governo que omitem ou embaraçam informações sobre os casos de COVID-19, não apenas se mostram irresponsáveis. Acabam por deixar todos em risco e vulnerabilidade, desde pessoas não infectadas até equipes médicas. Dificultam medidas de eficácia sanitária em nível local e também transfronteiriço e, obstacularizam os compromissos que assumiram quando se tornaram signatários da Organização Mundial da Saúde. De forma subsidiária, rompem com o Estado de Direito e agravam depressões nos mercados e na economia, cuja interdependência global é inegável.

Não há dúvidas que certas consequências do Covid-19 originaram-se de ato omissivo do Estado. A negligência estatal, assim, poderá despontar, caso se ateste que a adoção tempestiva de medidas profiláticas, como o fornecimento oportuno de equipamentos de proteção individual aos profissionais da saúde pública ou fechamento de fronteiras e o cancelamento de voos, principalmente internacionais, teria contribuído para combater a contaminação, reduzindo o risco de contagio e a velocidade de propagação do vírus.

Lembra-nos Freitas ${ }^{36}$ que:

A omissão causa o dano injusto que se consuma pelo nãocumprimento do dever estatal incontornável. Não há, com a devida vênia, nada de substancial que justifique tratamento radicalmente distinto entre ações e omissões, no modelo

35 STAFFEN, Márcio Ricardo. COVID-19 e a pretensão jurídica transnacional por transparência. Revista Eletrônica Direito \& Política. 2020. Disponível em: <https://siaiap32.univali.br/seer/index.php/rdp/article/view/16382/9272>. Acesso em: 9 ago. 2020, p. 142.

36 FREITAS, Juarez. A responsabilidade extracontratual do estado e o princípio da proporcionalidade. p. 381-401. 
SOUZA JUNIOR, Jarbas Paula de. Responsabilidade civil do Estado em tempos de COVID-19: breves considerações a luz das recomendações da Organização Mundial da Saúde e sob a ótica constitucional moderna dos Direitos e Garantias Fundamentais. Revista Eletrônica Direito e Política, Programa de Pós-Graduação Stricto Sensu em Ciência Jurídica da UNIVALI, Itajaí, v.15, n.3, 30 quadrimestre de 2020. Disponível em: www.univali.br/direitoepolitica - ISSN 1980-7791

constitucional brasileiro: a responsabilidade é proporcional seja por ações, seja por omissões danosas por agentes das pessoas jurídicas de direito público e de direito privado prestadoras dos serviços de titularidade do Poder Público.

Obviamente que, para a positivação da responsabilidade estatal, não só se faz necessário a demonstração da conduta omissiva, como a ocorrência do liame causal entre a conduta negativa (não-agir) e a contaminação desenfreada da população.

Ressoa desarrazoado imputar a integralidade das consequências da Pandemia Covid-19 aos comportamentos ou omissões perpetrados pelo Estado, visto tratar-se de fenômeno natural, imprevisível e de consequências muitas vezes inevitáveis. Porém, o advento da Pandemia constitui cenário propício a ensejar a adoção de medidas de enfrentamento que, como afirmado, podem, na hipótese de serem negligenciadas, resultar em danos para os particulares.

A eventual interligação entre a omissão estatal e a infecção de milhares de pessoas por Covid-19 deverá ser objeto de análises futuras no Brasil, no intuito de verificar-se a existência ou não do nexo de causalidade entre o não-agir público e os danos experimentados. Pondera Frazão ${ }^{37}$ que "fica claro que as excludentes de responsabilidade apenas poderão ser consideradas como tal, para fim de afastar a imputação, quando foram consideradas estranhas ao risco".

Em resenha específica sobre a responsabilidade civil na Administração Pública, Medauar $^{38}$ assim se manifesta:

[...] há um nítido caminho na responsabilidade civil do estado, sempre em prol da vítima. [...] A questão da responsabilidade civil do Estado precisa caminhar ainda mais, sempre colocando no centro dos estudos a vítima, que é na verdade a tônica dos estudos que vêm sendo feitos sobre a responsabilidade civil do Estado.

37 FRAZ̃̃o, Ana. Risco da empresa e caso fortuito externo. Disponível em: <http://civilistica.com/wp-content/uploads1/2016/07/Fraz\%C3\%A3o-civilistica.com-a.5.n.1.20163.pdf>. 2016. Acesso em 07 de ago. de 2020, p. 23.

38 MEDAUAR, Odete. Jornada sobre gestores públicos e responsabilidade civil na administração pública. Boletim de Direito Administrativo, 1/1, jan. 2004, p. 13. 
SOUZA JUNIOR, Jarbas Paula de. Responsabilidade civil do Estado em tempos de COVID-19: breves considerações a luz das recomendações da Organização Mundial da Saúde e sob a ótica constitucional moderna dos Direitos e Garantias Fundamentais. Revista Eletrônica Direito e Política, Programa de Pós-Graduação Stricto Sensu em Ciência Jurídica da UNIVALI, Itajaí, v.15, n.3, 30 quadrimestre de 2020. Disponível em: www.univali.br/direitoepolitica - ISSN 1980-7791

Por conseguinte, tratando-se a Pandemia Covid-19 de genuíno e inédito evento epidemiológico (situação de caso fortuito ou de força maior), com consequências e resultados, na maioria das ocorrências, inevitáveis, inicialmente seria descabido falar-se em dever de indenizar dos entes estatais.

Contudo, a nosso ver, lastreando-se na corrente constitucionalista moderna de Juarez Freitas - que relaciona a responsabilidade civil do Estado à eficácia, direta e imediata, dos direitos fundamentais -, o remédio adequado seria verificar se esta conduta negativa estatal, se a deficiência de atuação do Estado, contribuiu para implementação ou agravamento dos danos decorrentes do contágio do vírus COVID-19. Caso a respostas seja positiva estar-se-ia diante hipótese de responsabilização estatal, sem a análise do elemento volitivo culpa.

\section{CONSIDERAÇÕES FINAIS}

A crise sanitária internacional instalada pela Pandemia Covid-19, na atual Era da Informação, comprovou, indubitavelmente, o quão suscetível e vulnerável se encontra a humanidade. Eclodiram situações jamais vivenciadas na Era Moderna, como o colapso de inúmeros sistemas de saúde em todo mundo, em função da sobrecarga de pacientes infectados a necessitar, simultaneamente, de assistência médica.

Evidenciou-se, mais do que nunca, a importância de se reinventar o Direito Internacional e o papel das Organizações Internacionais, sobretudo, a Organização Mundial da Saúde, porquanto referidos organismos internacionais se ressentem de mecanismos eficientes para impor suas decisões (ausência de força vinculante e de subordinação).

O desprezo aos direitos humanos - considerados como um patrimônio da humanidade por Rodotà ${ }^{39}$-, representado pela relativização das recomendações da Organização Mundial da Saúde, foram uma constante indesejável, mas presente nas diversas ações governamentais mundo afora.

${ }^{39}$ RODOTÀ, Stefano. El derecho a tener derechos. Madri: Trotta, 2012, p. 121. 
SOUZA JUNIOR, Jarbas Paula de. Responsabilidade civil do Estado em tempos de COVID-19: breves considerações a luz das recomendações da Organização Mundial da Saúde e sob a ótica constitucional moderna dos Direitos e Garantias Fundamentais. Revista Eletrônica Direito e Política, Programa de Pós-Graduação Stricto Sensu em Ciência Jurídica da UNIVALI, Itajaí, v.15, n.3, 30 quadrimestre de 2020. Disponível em: www.univali.br/direitoepolitica - ISSN 1980-7791

Esta infeliz rotina não foi diferente no Brasil, em nosso território chegamos ao disparate de não só desrespeitar as orientações da Organização Mundial da Saúde, como sequer conseguirmos obter um consenso, a respeito de qual norma seguir no enfrentamento da Covid-19, entre os membros do atual governo.

O descumprimento das recomendações internacionais e, consequentemente, suas graves consequências, não podem ser tipificadas, como condutas aceitáveis, inevitáveis. Era totalmente previsível que, em um país de dimensões continentais, como o Brasil, com um contingente de miseráveis de 13,5 milhões de pessoas $^{40}$ - quase em sua totalidade, sobrevivendo abaixo da linha da pobreza, em locais precários, com absoluta privação de algumas necessidades básica como água potável, energia elétrica, rede de esgoto -, os efeitos, não só humanos como econômicos, da Pandemia Covid-19 seriam devastadores.

É notório, que o Estado não se trata de um "segurador, garantidor universal" e, como referido alhures, respeitadas as recomendações de prevenção contra a Covid-19, inseridas dentro de protocolos cientificamente reconhecidos, ainda que, insuficiente para eliminar por completo os riscos de contágio, não há que se falar em responsabilidade civil e dever de reparar pelo Estado.

O quadro sanitário instalado, a partir da Pandemia Covid-19, catapultou a concretização dos direitos fundamentais, singularmente o meta-princípio da dignidade da pessoa humana. O ideal kantiano da necessidade do ser humano ser "tratado não como objeto, mas como um fim em si mesmo" potencializou-se ainda mais ${ }^{41}$.

Roberto $^{42}$ aduz que:

Retrato do Estado Democrático de Direito existente e em consolidação no Brasil, o fundamento da dignidade da pessoa humana, depois do direito à vida, é a viga-mestra dos direitos e garantias fundamentais proporcionados pela

\footnotetext{
40 JIMÉNEZ, Carla. Extrema pobreza sobe e brasil já soma 13,5 milhões de miseráveis. Disponível em: < https://brasil.elpais.com/brasil/2019/11/06/politica/1573049315_913111.html>. jun. 2019. Acesso em 10 de ago. de 2020.

${ }^{41}$ BORGES, Gustavo. Erro médico nas cirurgias plásticas. São Paulo: Atlas, 2014, p. 86.

42 ROBERTO, Luciana Mendes Pereira. Responsabilidade civil do profissional de saúde \& consentimento informado. 3. ed. Curitiba: Juruá, 2012, p. 37.
} 
SOUZA JUNIOR, Jarbas Paula de. Responsabilidade civil do Estado em tempos de COVID-19: breves considerações a luz das recomendações da Organização Mundial da Saúde e sob a ótica constitucional moderna dos Direitos e Garantias Fundamentais. Revista Eletrônica Direito e Política, Programa de Pós-Graduação Stricto Sensu em Ciência Jurídica da UNIVALI, Itajaí, v.15, n.3, 30 quadrimestre de 2020. Disponível em: www.univali.br/direitoepolitica - ISSN 1980-7791

Constituição Federal. Não há que se falar em sistema jurídico legítimo se não fundado na garantia da intangibilidade da dignidade da pessoa humana.

Não é descomedido afirmar que, a Pandemia Covid-19, poderá consolidar a compreensão constitucional moderna de que à responsabilidade civil do Estado vincula-se, imperiosamente, a eficácia, direta e imediata, dos direitos fundamentais, vedando-se excessos e omissões.

Com efeito, é incontroverso o fato de que certas consequências da Pandemia Covid-19 originaram-se de ato omissivo do Estado. Hipóteses como insuficiência de leitos, bem como escassez de equipamentos de proteção individual para os profissionais da saúde pública, podem motivar, de acordo com o concreto, a responsabilidade civil estatal por omissão.

Neste sentido, devemos considerar que a não observância das recomendações preventivas no combate a Pandemia Covid-19 poderá ensejar a responsabilização civil do Estado, independentemente de culpa (tanto por condutas comissivas como por omissões), protegendo-se a vítima e não restando nenhum dano sem reparação, desde se comprove que a deficiência de atuação do Estado contribuiu para implementação ou agravamento dos danos decorrentes do contágio do vírus Covid-19.

Enfim, a falta de sensibilidade estatal poderá ocasionar, caso se confirme que a ausência da adoção oportuna das medidas de prevenção contribui para a disseminação descontrolada do vírus, a responsabilização civil do Estado, dado tratar-se à saúde de um direito fundamental, sendo, o atendimento hospitalar adequado, um ônus legal do Estado.

\section{REFERÊNCIAS DAS FONTES CITADAS}

ALMEIDA, Paulo Roberto de. Revista brasileira de política internacional. v. 40, $\quad$ n. 2. jul./dez. $1997 . \quad$ Disponível em: <https://www.scielo.br/scielo.php?script=sci_arttext\&pid=S003473291997000200014\&lng=pt\&tlng=pt>. Acesso em: 06 ago. 2020.

BAPTISTA, Patrícia. Transformações do direito administrativo. Rio de Janeiro: Renovar, 2003. 
SOUZA JUNIOR, Jarbas Paula de. Responsabilidade civil do Estado em tempos de COVID-19: breves considerações a luz das recomendações da Organização Mundial da Saúde e sob a ótica constitucional moderna dos Direitos e Garantias Fundamentais. Revista Eletrônica Direito e Política, Programa de Pós-Graduação Stricto Sensu em Ciência Jurídica da UNIVALI, Itajaí, v.15, n.3, 30 quadrimestre de 2020. Disponível em: www.univali.br/direitoepolitica - ISSN 1980-7791

BERNARDO, Paulo. Brasil teve papel direto na fundação da OMS: entenda o que é a função da organização. Disponível em: <https://saude.estadao.com.br/noticias/geral,brasil-teve-papel-direto-nafundacao-da-oms-entenda-o-que-e-e-a-funcao-da-organizacao,70003256316>. Acesso em: 06 ago. 2020.

BISNETO, Cícero Dantas; SANTOS, Romualdo Baptista dos; CAVET, Caroline Amadori. Responsabilidade civil do estado por omissão e por incitação na pandemia da covid-19. Revista IBERC. v. 3, n. 2, maio/ago. 2020. Disponível em: $<$ https://revistaiberc.responsabilidadecivil.org/iberc/article/view/111>. Acesso em 07 de ago. de 2020.

BORGES, Gustavo. Erro médico nas cirurgias plásticas. São Paulo: Atlas, 2014.

BRASIL, Constituição Federal. 1988. Disponível em: <http://www.planalto.gov.br/ccivil_03/constituicao/constituicao.htm>. Acesso em: 7 ago. 2020.

BRASIL, Decreto no 26.042 (Constituição da Organização Mundial da Saúde). 1948. Disponível em: <https://www2.camara.leg.br/legin/fed/decret/19401949/decreto-26042-17-dezembro-1948-455751-publicacaooriginal-1-pe.html> . Acesso em: 7 ago. 2020.

BROWN, Theodore M.; CUETO, Marcos; FEE, Elizabeth. A transição de saúde pública 'internacional' para 'global' e a Organização Mundial da Saúde. Disponível em: <https://www.scielo.br/scielo.php?script=sci_arttext\&pid=S0104$59702006000300005 \&$ lng =pt\&tlng=pt> . 2006. Acesso em 07 de ago. de 2020.

CABRAL, Cristiane Helena de Paula Lima. Organização mundial da saúde e sua atuação no âmbito da saúde pública internacional. In: BAHIA, Saulo José Casali Bahia; MARTINS, Carlos Eduardo Behrmann Rátis (Coord.). Direitos e deveres fundamentais em tempos de coronavírus. v. 2. São Paulo: Editora Iasp, 2020.

CAVAlieRI FILHO, Sergio. Programa de responsabilidade civil. 14. ed. São Paulo: Atlas. 2020.

DIMOULIS, Dimitri; MARTINS, Leonardo. Teoria geral dos direitos fundamentais. São Paulo: atlas, 2012.

FERRAJOLI, Luigi. O vírus põe a globalização de joelhos. Revista do Instituto Humanitas UNISINOS. 2020. Disponível em: <http://www.ihu.unisinos.br/78noticias/597204-o-virus-poe-a-globalizacao-de-joelhos-artigo-de-luigi-ferrajoli > . Acesso em: 7 ago. 2020. 
SOUZA JUNIOR, Jarbas Paula de. Responsabilidade civil do Estado em tempos de COVID-19: breves considerações a luz das recomendações da Organização Mundial da Saúde e sob a ótica constitucional moderna dos Direitos e Garantias Fundamentais. Revista Eletrônica Direito e Política, Programa de Pós-Graduação Stricto Sensu em Ciência Jurídica da UNIVALI, Itajaí, v.15, n.3, 30 quadrimestre de 2020. Disponível em: www.univali.br/direitoepolitica - ISSN 1980-7791

FLEINER-GERSTER, Thomas. Teoria geral do estado. São Paulo: Martins Fontes, 2006.

FRAZÃO, Ana. Risco da empresa e caso fortuito externo. Disponível em: $<$ http://civilistica.com/wp-content/uploads1/2016/07/Fraz\%C3\%A3ocivilistica.com-a.5.n.1.2016-3.pdf>. 2016. Acesso em 07 de ago. de 2020.

FREITAS, Juarez. A responsabilidade extracontratual do estado e o princípio da proporcionalidade: vedação de excesso e de omissão. Revista de Direito Administrativo. n. 241. Rio de Janeiro, 2005.

JIMÉNEZ, Carla. Extrema pobreza sobe e brasil já soma 13,5 milhões de miseráveis.

Disponível

em:

https://brasil.elpais.com/brasil/2019/11/06/politica/1573049315_913111.html>. jun. 2019. Acesso em 10 de ago. de 2020.

MEDAUAR, Odete. Jornada sobre gestores públicos e responsabilidade civil na administração pública. Boletim de Direito Administrativo, 1/1, jan. 2004.

MEZZAROBA, Orides; MONTEIRO, Cláudia Servilha. Manual de metodologia da pesquisa no direito. 5 ed. São Paulo: Saraiva, 2009.

OMS. Organização Mundial da Saúde. Disponível em: <https://www.who.int/es>. Acesso em: 06 ago. 2020.

OPAS. Organização pan-americana da saúde. Disponível em: <https://www.paho.org/bra/index.php?option=com_content\&view=article\&id=88 5:opas-oms-nobrasil\&Itemid=672>. Acesso em: 06 ago. 2020.

PECES-BARBA, Gregório. Curso de derechos fundamentales. Teoria General. Madri: Universidad Carlos III, 1995.

ROBERTO, Luciana Mendes Pereira. Responsabilidade civil do profissional de saúde \& consentimento informado. 3. ed. Curitiba: Juruá, 2012.

RODOTÀ, Stefano. EI derecho a tener derechos. Madri: Trotta, 2012.

STAFFEN, Márcio Ricardo. COVID-19 e a pretensão jurídica transnacional por transparência. Revista Eletrônica Direito \& Política. 2020. Disponível em: <https://siaiap32.univali.br/seer/index.php/rdp/article/view/16382/9272>.

Acesso em: 9 ago. 2020. 